\title{
MARSH HAWKS FEEDING ON SNOWSHOE HARES
}

ROBERT W. NERO, Manitoba Wildlife Branch, Box 14, 1495 St. James Street, Winnipeg, Manitoba. R3H OW9

On 17 April 1982. Herbert W.R. Copland and I observed two male Marsh Hawks, about a mile apart, each feeding on the fresh carcass of a Snowshoe Hare. This was at midday on a forestry road in boreal forest habitat about 45 miles southeast of Winnipeg. Both hares appeared to be freshly killed and were lying on the cleared right-ofway. Because of the light traffic on this particular road and the location of the hares it seemed unlikely that they were roadkills, hence we believed them to be fresh prey. (Admittedly it would have been wise to skin the hares to ascertain that they had been killed by the birds.) Both birds were feeding on the entrails or internal organs. The hares were still in partly white pelage and would have been conspicuous in the snow-free landscape.

In each case the birds flushed from the roadside at the close approach of our car and then, while we were stopped, flew in close circles about us, rising up over adjacent trees and dropping low over the road. As soon as we drove some 50 feet away, each bird returned to its prey.

Spencer G. Sealy reports nesting Marsh Hawks in southeastern Alberta feeding on adult Nuttall's Cottontails. ${ }^{5}$ The latter species, as determined by Sealy from adult museum specimens, have an average weight of 984 grams. Snowshoe Hares are larger, averaging 1,500 grams, according to A. W. Frank Banfield (The Mammals of Canada. Natl. Museums of Canada. Univ. Toronto Press, Toronto. 1974). William $R$. Hecht found remains of young Snowshoe Hares at two Marsh Hawks nests at Delta, Manitoba. ${ }^{4}$
Ivan R. Tomkins states that in the saltwater marshes of South Carolina and Georgia the Marsh Hawk's winter food is mostly Marsh Rabbits. ${ }^{2}$ According to William J. Hamilton, Jr. these rabbits average 1,600 grams. ${ }^{3}$ On the basis of weight, it appears therefore that Marsh Rabbits are even larger than Snowshoe Hares.

Clearly, the Marsh Hawk is capable of taking large mammalian prey, the Snowshoe Hare being vulnerable to this species. Because the Snowshoe Hare is largely a woodland animal it may be less available than other prey. On the other hand hares regularly move out to feed on rights-of-way where they would be open to predation by the stealthy flight of hunting Marsh Hawks. This would be true especially in the case of adult birds, possibly experienced in taking rabbits.

I would like to thank Keith L. Bildstein and Spencer G. Sealy for directing my attention to pertinent literature. Fran Hamerstrom noted that we had failed to determine whether the Marsh Hawks had actually killed the hares.

'BANFIELD, A. W. F. 1974. The mammals of Canada. Nat. Mus. of Canada, University of Toronto Press, Toronto.

${ }^{2}$ BENT, A. C. 1961 Reprint. Life histories of North American birds of prey. Part 1. Dover Publ., New York.

${ }^{3}$ HAMILTON, W. J., Jr. 1963. Mammals of eastern United States. Hafner Publ. Co. Inc., New York.

${ }^{4} \mathrm{HECHT}$, W. R. 1951. Nesting of the Marsh Hawk at Delta, Manitoba. Wilson Bull. 63:167-177

${ }^{5}$ SEALY, S. G. 1965. Marsh Hawk preys on cottontails. Blue Jay 23(1):25. 